\title{
Purchasing habits of students toward Green Marketing in Nueva Ecija, Philippines
}

\author{
Kim Edward S. Santos, MBA
}

\author{
Wesleyan University-Philippines \\ kimnyte@gmail.com
}

\begin{abstract}
Green products not only help your business stand out in a saturated market, and they often help alleviate some of the burden humans take on the environment. This paper examined the green consumer values, consumer behavior towards green products, green marketing on consumer purchase intention, and factors affecting the purchase of green products. The study used quantitative descriptive method. This research surveyed 134 students from private schools and institutions in Nueva Ecija. . It was concluded the following consumers: (1) are using products that are environmental friendly, does not mean they are automatically environment responsible and are not related of environmental concerns, but should be a collaborative effort of all individuals; (3) depends on the price and their awareness on such as preference in choosing green products over conventional products to their purchase habits; (2) believe it is not only the government and business that will take charge; and (4) who have past experience on green products affect their purchase intention. The researcher recommends to educate consumers on their social responsibility in purchasing, particularly to choose green products over conventional products. Likewise, organizations and corporations to target their customers and improve their brand image can emphasize green packaging. And, government agencies should undertake environmental protection programs in order to raise green awareness.
\end{abstract}

Keywords-Green Marketing, Green Products, Ecofriendly products.

\section{INTRODUCTION}

Green products not only help your business stand out in a saturated market, and they often help alleviate some of the burden humans take on the environment. Green marketing is concerned with conducting all marketing efforts in an environmentally responsible manner (Kinoti, 2011). Green marketing include product modification, process modifications, packaging modifications, and advertising modifications as businesses employ green marketing to meet cost or profit concerns (Singh \& Pandey, 2012).

With the environment and environmental challenges gaining prominence in the public's mind, businesses have begun to adapt their manufacturing, goods or service generation, and therefore their green marketing tactics (Boztepe, 2012). Consumers are becoming increasingly concerned about environmental deterioration and the detrimental impact of their product and service purchases on the environment (Bhatia \& Jain, 2013). Businesses can most successfully increase consumers' purchase intention for green products by adopting a green marketing concept for the product, technology, production, and promotion (Wu \& Chen, 2014).

Governments should conduct campaigns to increase public knowledge of eco-labels, as this study demonstrates that consumer belief in eco-labels has a major impact on their green purchase behavior (Rahbar \& Wahid, 2011). Marketers also have a responsibility to educate consumers about the importance of and benefits of green products in comparison to non-green items; however, consumers must be willing to pay extra to preserve a cleaner, greener environment (Misha \& Sharma, 2010).

In light of these findings, the researcher sought to determine students' purchasing habits about green marketing in Nueva Ecija, Philippines.

\section{OBJECTIVES OF THE STUDY}

This paper examined the green consumer values, consumer behavior towards green products, green marketing on consumer purchase intention, and factors affecting the purchase of green products.

\section{METHODOLOGY}

The study used quantitative descriptive method as it is a basic research approach which looks at the situation as it exists in its present state (Williams, 2007). This research surveyed 134 students from private schools and institutions in Nueva Ecija. The study employed survey research because it integrates research methods through source material examination and evaluation, data analysis and interpretation, and generalization and prediction (Salaria, 2012). The questionnaire was adopted from Haws et al. (2010), Cripsell (2001) and Ansar (2013). 


\section{RESULTS AND DISCUSSIONS}

Table 1. Green consumer value measure

\begin{tabular}{|c|c|c|}
\hline Statement & Mean & $\begin{array}{c}\text { Verbal } \\
\text { Interpretation }\end{array}$ \\
\hline 1. It is important to me that the products I use do not harm the environment & 4.32 & Strongly Agree \\
\hline $\begin{array}{l}\text { 2. I consider the potential environmental impact of my actions when making many of } \\
\text { my decisions }\end{array}$ & 2.95 & Somewhat Agree \\
\hline 3. My purchase habits are affected by my concern for our environment & 3.27 & Neutral \\
\hline 4. I am concerned about wasting the resources of our planet. & 4.05 & Somewhat Agree \\
\hline 5. I would describe myself as environmentally responsible. & 3.37 & Neutral \\
\hline $\begin{array}{l}\text { 6. I am willing to be inconvenienced in order to take actions that are more } \\
\text { environmentally friendly. }\end{array}$ & 3.45 & Somewhat Agree \\
\hline Average Weighted Mean & 3.57 & Somewhat Agree \\
\hline
\end{tabular}

\section{Legend Verbal Interpretation (VI)}

4.20 - 5.00 Strongly Agree

3.40 - 4.19 Somewhat Agree

$2.60-3.39$ Neutral

1.80 - 2.59 Somewhat Disagree

1.00 - 1.79 Strongly Disagree

Table 1 presents the result of the green consumer value measure. Consumer - respondents scored an average weighted mean of 3.57 that has a verbal interpretation of "Somewhat Agree". They strongly agreed on statement 1 " It is important to me that the products I use do not harm the environment" (Mean =4.32). However, their response was neutral on statement 5 "I would describe myself as environmentally responsible." (Mean = 3.37) and Statement 3 "My purchase habits are affected by my concern for our environment" (Mean $=3.27$ ). The results show that, though, consumers are using products that are environmental friendly, do not mean they are automatically environment responsible and are not related to their purchase habits. The analysis supports Davidson, Yantis, Norwood, and Montano's (1985) hypothesis that consumers' attitudes are influenced by their knowledge and personal experiences.

Table 2. Consumer behavior towards green products

\begin{tabular}{|c|c|c|}
\hline Statement & Mean & $\begin{array}{c}\text { Verbal } \\
\text { Interpretation }\end{array}$ \\
\hline 1. I buy only green products. I & 2.98 & Neutral \\
\hline 2. I spend time and effort in environmental activities such as recycling. & 4.31 & Strongly Agree \\
\hline 3. I believe that an individual can do much to promote the environment. & 3.06 & Neutral \\
\hline $\begin{array}{l}\text { 4. I am able to buy green products but I don't have the time and energy for } \\
\text { environmental activities. }\end{array}$ & 3.26 & Neutral \\
\hline $\begin{array}{l}\text { 5. I can buy green products from time to time but I am not involved in any } \\
\text { environmental activities }\end{array}$ & 3.47 & Somewhat Agree \\
\hline $\begin{array}{l}\text { 6. I do not buy green products. I believe that business and government should be fixing } \\
\text { environmental problems.* }\end{array}$ & 3.34 & Neutral \\
\hline 7. I am the least involved in environmentalism. * & 2.89 & Neutral \\
\hline $\begin{array}{l}\text { 8. I believe that there is not much that an individual can do in solving environmental } \\
\text { problems. * }\end{array}$ & 3.68 & $\begin{array}{l}\text { Somewhat } \\
\text { Disagree }\end{array}$ \\
\hline 9. It should be the government and business which should promote the environment. * & 3.43 & $\begin{array}{l}\text { Somewhat } \\
\text { Disagree }\end{array}$ \\
\hline Average Weighted Mean & 3.38 & Neutral \\
\hline
\end{tabular}


Legend Verbal Interpretation(VI) Reverse Verbal Interpretation (RVI)

4.20 - 5.00 Strongly Agree

$3.40-4.19$ Somewhat Agree

$2.60-3.39$ Neutral

$1.80-2.59$ Somewhat Disagree

1.00 - 1.79 Strongly Disagree
Strongly Disagree

Somewhat Disagree

Neutral

Somewhat Agree

Strongly Agree
Table 2 shows the result of consumer behavior towards green products. Consumer - respondents got an average weighted mean of 3.38, which has a verbal interpretation of "Neutral". Consumer - respondents strongly agreed on Statement 2 "I spend time and effort in environmental activities such as recycling." (Mean $=4.31$ ). This shows how they engage themselves in protecting the environment. On the other hand, they somewhat disagreed on Statement 8 "I believe that there is not much that an individual can do in solving environmental problems." (Mean = 3.68), Statement 5 "I can buy green products from time to time but I am not involved in any environmental activities" (Mean = 3.47), and Statement 9 "It should be the government and business which should promote the environment." (Mean = 3.47). These results indicate that consumer - respondents believe it is not only the government and business that will take charge of environmental concerns, but should be a collaborative effort of all individuals. Further, participating in some environmental activities should not limited to buying green products. In alignment, consumers lack green knowledge, according to Cherian and Jacob (2012), and as a result of this lack of awareness, organizations are still hesitant to invest in the development of green products, fearing that their investment would not provide enough returns.

Table 3. Purchasing the Product

\begin{tabular}{|c|c|c|}
\hline Statement & Mean & $\begin{array}{c}\text { Verbal } \\
\text { Interpretation }\end{array}$ \\
\hline $\begin{array}{l}\text { 1. I consider the ill effects of manufacturing and consumption on the natural } \\
\text { environment. }\end{array}$ & 3.34 & Neutral \\
\hline 2. I prefer green products over conventional products & 3.19 & Neutral \\
\hline 3. I feel that green products are priced higher as compared to conventional product. & 4.18 & Somewhat Agree \\
\hline 4. I feel that price of green product affects my purchase behavior & 3.13 & Neutral \\
\hline Average Weighted Mean & 3.46 & Somewhat Agree \\
\hline
\end{tabular}

Legend Verbal Interpretation (VI)

4.20 - 5.00 Strongly Agree

3.40 - 4.19 Somewhat Agree

$2.60-3.39$ Neutral

$1.80-2.59$ Somewhat Disagree

1.00 - 1.79 Strongly Disagree

Table 3 shows the results on how green marketing impacts consumer purchasing. Consumer - respondents scored an average weighted mean of 3.46 that has a verbal interpretation of " Somewhat Agree". Particularly, Statement 3 "I feel that green products are priced higher as compared to conventional product." got mean of 4.18 and with verbal interpretation of "somewhat Agree". All other statements got neutral response. The result illustrates that green marketing somehow affects consumer purchasing. Noticeably, consumer's preference in choosing green products over conventional products depends on the price and their awareness on such. Ansar (2013) showed advertisements, price, and green packaging all had a direct and favorable impact on the decision to buy green. According to the findings of this study, advertisements increased green buying intent. 
Table 4. Factors affecting the purchase of green products

\begin{tabular}{rlcc}
\hline \multicolumn{1}{c}{ Factor } & Mean & Verbal Interpretation \\
\hline 1. & Product Price & 4.08 & Somewhat Agree \\
2. Awareness about Green Products & 3.30 & Neutral \\
3. & Availability of Green Products & 2.97 & Neutral \\
4. & Past Experience & 4.38 & Strongly Agree \\
5. & Information provided on product & 4.06 & Somewhat Agree \\
\hline & Average Weighted Mean & 3.76 & Somewhat Agree \\
\hline
\end{tabular}

\section{Legend Verbal Interpretation (VI)}

4.20 - 5.00 Strongly Agree

3.40 - 4.19 Somewhat Agree

$2.60-3.39$ Neutral

1.80 - 2.59 Somewhat Disagree

1.00 - 1.79 Strongly Disagree

Table 4 presents the factors affecting the purchase of green products. Results show that consumer - respondents strongly agreed on Statement 4 " Past Experience" (Mean $=4.38$ ) and they somewhat agreed on Statement 1 "Product Price" (Mean = 4.08) and Statement 5 " Information provided on product" (Mean $=4.06)$ are the factors on purchasing green products. The analysis supports Davidson, Yantis, Norwood, and Montano's (1985) hypothesis that consumers' attitudes are influenced by their knowledge and personal experiences. Further, this also supports the findings of the study of Jaju (2016), which found that green packaging and branding, the importance of green products, and premium green pricing had a direct impact on customer behavior, leading to green purchases. The study also demonstrated why there is a link between eco-labelling, green branding, green pricing, and consumer environmental behavior.

\section{CONCLUSIONS AND RECOMMENDATIONS}

The present study examined the green consumer values, consumer behavior towards green products, green marketing on consumer purchase intention, and factors affecting the purchase of green products. It was concluded the following consumers: (1) are using products that are environmental friendly, does not mean they are automatically environment responsible and are not related of environmental concerns, but should be a collaborative effort of all individuals; (3) depends on the price and their awareness on such as preference in choosing green products over conventional products to their purchase habits; (2) believe it is not only the government and business that will take charge; and (4) who have past experience on green products affect their purchase intention.
The researcher recommends to educate consumers on their social responsibility in purchasing, particularly to choose green products over conventional products. Likewise, organizations and corporations to target their customers and improve their brand image can emphasize green packaging. And, government agencies should undertake environmental protection programs in order to raise green awareness.

\section{REFERENCES}

[1] Ansar, N. (2013). Impact of green marketing on consumer purchase intention. Mediterranean Journal of Social Sciences, 4(11), 650-650.

[2] Bhatia, M., \& Jain, A. (2013). Green marketing: A study of consumer perception and preferences in India. Electronic Green Journal, 1(36).

[3] Boztepe, A. (2012). Green marketing and its impact on consumer buying behavior. European Journal of Economic \& Political Studies, 5(1).

[4] Cherian, J., \& Jacob, J. (2012). Green marketing: A study of consumers' attitude towards environment friendly products. Asían social science, 8(12), 117.

[5] Crispell, D. (2001). Going Green(ish). Public Perspective, September/October 2001, pp. 28-30.

[6] Davidson, A. R., Yantis, S., Norwood, M. and Montano, D. E. (1985). Amount of Information about the Attittude Object and Attitude Behavior Consistency. Journal of Personality and Social Psychology, Vol. 49, No. 5, pp. 1184-1198. http://dx.doi.org/10.1037/0022- 3514.49.5.1184 Davis, Joel J. (1992).

[7] Haws, K. L., Winterich, K. P., and Naylor, R. W. (2010). Green Consumer Values. Handbook of Marketing Scales, 3rd Edition, pp. 172-173

[8] Jaju, A. (2016). A study of the Impact of Green Marketing on Consumer Purchasing Patterns and 
Decision Making in Telangana, India (Doctoral dissertation, Dublin, National College of Ireland).

[9] Kinoti, M. W. (2011). Green marketing intervention strategies and sustainable development: A conceptual paper. International journal of business and social science, 2(23).

[10] Mishra, P., \& Sharma, P. (2010). Green marketing in India: Emerging opportunities and challenges. Journal of Engineering, Science and Management Education, 3(1), 9-14.

[11] Rahbar, E., \& Wahid, N. A. (2011). Investigation of green marketing tools' effect on consumers' purchase behavior. Business strategy series.

[12] Salaria, N. (2012). Meaning of the term descriptive survey research method. International journal of transformations in business management, 1(6), 1-7.

[13] Singh, P. B., \& Pandey, K. K. (2012). Green marketing: policies and practices for sustainable development. Integral Review, 5(1), 22-30.

[14] Williams, C. (2007). Research methods. Journal of Business \& Economics Research (JBER), 5(3). https://doi.org/10.19030/jber.v5i3.2532

[15] Wu, S. I., \& Chen, Y. J. (2014). The impact of green marketing and perceived innovation on purchase intention for green products. International Journal of Marketing Studies, 6(5), 81. 